\title{
The City Commercial Bank's Credit Rating on Steel Distribution Industry in China
}

\author{
Liqiong Yang ${ }^{1}$ \\ ${ }^{1}$ School of Economics, Northwest University for Nationalities, Lanzhou, China \\ Correspondence: Liqiong Yang, School of Economics, Northwest University for Nationalities, Lanzhou 730124, \\ China. E-mail: 1123002683@qq.com
}

Received: August 17, 2015

Accepted: September 3, 2015

Online Published: October 7, 2015

doi:10.5430/jms.v6n4p29

URL: http://dx.doi.org/10.5430/jms.v6n4p29

This work was supported by the Fundamental Research Funds for the Central University of Northwest University for Nationalities (Grant No: ZYZ2012013)

\begin{abstract}
Small and Medium-sized Enterprises make a significant contribution to economic growth in China. City Commercial Banks mainly serve the local Small Medium Enterprises in China. Every City Commercial Bank provides Small and Medium-sized Enterprises clients the credit rating grade, and it decides on whether to give them financial support according to credit rating result. Usually, banks work on credit rating of Small and Medium-sized Enterprises according to the characteristics of the industry. This work gives the designing process of credit rating system of steel distribution industry. By using questionnaire and analytic hierarchy process, researcher chose a City Commercial Bank as an example and designed a credible credit rating index system for steel distribution industry.
\end{abstract}

Keywords: credit rating, The City Commercial Bank, judgment matrix

\section{Introduction}

City Commercial Banks mainly serve for the local Small and Medium-sized Enterprises in China. It is an important work for these banks to give the Small and Medium-sized Enterprise's credit rating objectively. According to this, City Commercial Banks need to establish a new set of credit evaluation system to help them find relatively high quality clients from the Small and Medium-sized Enterprises. In China, Small and Medium-sized Enterprises exist widely in most industries, except for their natural characteristics themselves. On the other side, each Small and Medium-sized Enterprises also have regional and industrial characteristics obviously. Therefore, City Commercial Banks need to classify Small and Medium-sized Enterprises customers according to the industry, and design different credit evaluation systems for different industries.

For many provinces which regard selling resources as the main industry, steel distribution industry may be the main force in the local Small and Medium-sized Enterprises. Therefore, it is meaningful to design credit rating system for this kind of Small and Medium-sized Enterprises.

\section{Research Methodology}

There are various research methods for credit rating, which can be generally divided into three types: qualitative analysis, quantitative analysis and the combination of qualitative and quantitative analysis. These three methods include many concrete methods. Researcher uses Analytic Hierarchy Process (AHP), which belongs to the combination of qualitative and quantitative methods. AHP was firstly proposed by professor Sadie in the University of Pittsburgh in the 1970' s. AHP which is a combination of qualitative analysis and quantitative analysis is an analytic method on multiple criteria decision. Specifically, applying AHP to determine the index weight consists of four basic steps: First, establish a hierarchy of index system. Second, structure judgment matrix. Third, calculate the weight of each level. Forth, find the consistency of judgment matrix. 


\section{How to Design Steel Distribution Industry Credit Rating System}

\subsection{How to Build Index System}

Credit rating index system is divided into three levels: the target layer, criterion layer and index layer, and these three levels can also be named as primary-class index layer, the secondary-class index layer and the third-class layer. The researcher chose a City Commercial Bank in the northwestern China, and selected a group of people in the bank who are mainly engaged in the credit work. Research also made a survey in the form of questionnaire among these people. The design on questionnaire took the relevant literature and the existing credit evaluation index system of this bank into consideration. Initially, researcher set up 5 primary-class indexes, 16 secondary-class indexes, 67 third-class indexes. Finally, 40 selected questionnaires serve as the basis of statistical index screening and weight calculating.

First of all, there is an option of "whether to delete" for each index on the questionnaire. Then the researcher figures out the number of this option for each index. If there is any figure that is beyond the normal range in the index, then this figure should be deleted. What's more, part of figures have not apparent features, so researcher is not sure whether to delete, and just determines to calculate the coefficient of variation (CV). CV is bigger, this index is more important, and vice versa. Finally, researcher determines 5 indexes in primary layer, 14 indexes secondary layer, 42 indexes in third layer.

\subsection{How to Construct Judgment Matrix}

After researcher builds the structure of index system, the relationship among indexes should be determined. Next, construct judgment matrix by comparing the importance of these indexes in the high lever which are at same layer. That is one factor such as criterion. It's a corresponding dominant factor to the next level. Through comparing two of them, researcher determines various factors of relative importance of certain factors on same level and gives a certain score.

Score of every index is from calculating CV according to the statistics of the questionnaire. Each index can be classed from extremely important, very important, important, generally to less important that match with 1, 2, 3, 4, 5 five values in turn, and then researcher calculates matrix and makes a comparison between two indexes at the same level in details one by one according to which one is more important. According to their importance, the comparison of importance is various, an integer as a result, on the contrary a score as a result, comparing rules is row rather than column values. A judgment matrix shows a group of administrative relationship. The index system has total eighteen judgment matrix showed by figure 1 and table 1. Note: you can read table 1 and find every symbol representing every index, then read every judgment matrix. For example, U1 means Market evaluation, and you can find relationship between $\mathrm{U} 1, \mathrm{C} 1$ and $\mathrm{C} 2$. 


\begin{tabular}{|c|c|c|c|c|c|c|c|c|c|c|c|c|c|c|c|c|c|}
\hline U1 & $\mathrm{C} 1$ & $\mathrm{C} 2$ & & U2 & $\mathrm{C} 3$ & $\mathrm{C} 4$ & & U4 & $\mathrm{C} 10$ & C11 & $\mathrm{C} 12$ & U5 & $\mathrm{C} 13$ & $\mathrm{C} 14$ & & & \\
\hline $\mathrm{C} 1$ & 1 & 1 & & $\mathrm{C} 3$ & 1 & 3 & & $\mathrm{C} 10$ & 1 & $1 / 3$ & $1 / 2$ & $\mathrm{C} 13$ & 1 & $1 / 2$ & & & \\
\hline \multirow[t]{2}{*}{$\mathrm{C} 2$} & 1 & 1 & & $\mathrm{C} 4$ & $1 / 3$ & 1 & & $\mathrm{C} 11$ & 3 & 1 & 2 & $\mathrm{C} 14$ & 2 & 1 & & & \\
\hline & & & & & & & & $\mathrm{C} 12$ & 2 & $1 / 2$ & 1 & & & & & & \\
\hline U3 & $\mathrm{C} 5$ & C6 & $\mathrm{C} 7$ & $\mathrm{C} 8$ & C9 & & & & & & & C3 & D5 & D6 & D7 & D8 & D9 \\
\hline C5 & 1 & 3 & $1 / 2$ & 2 & $1 / 3$ & & $\mathrm{C} 1$ & D1 & D2 & D3 & D4 & D5 & 1 & 1 & 2 & $1 / 4$ & $1 / 2$ \\
\hline C6 & $1 / 3$ & 1 & $1 / 4$ & $1 / 2$ & $1 / 4$ & & D1 & 1 & 3 & 4 & 2 & D6 & 1 & 1 & 2 & $1 / 4$ & $1 / 2$ \\
\hline $\mathrm{C} 7$ & 2 & 4 & 1 & 3 & 1 & & D2 & $1 / 3$ & 1 & 2 & $1 / 2$ & D7 & $1 / 2$ & 2 & 2 & $1 / 5$ & $1 / 3$ \\
\hline C8 & $1 / 2$ & 2 & $1 / 3$ & 1 & $1 / 3$ & & D3 & $1 / 4$ & $1 / 2$ & 1 & $1 / 3$ & D8 & 4 & 4 & 5 & 1 & 3 \\
\hline C9 & 3 & 4 & 1 & 3 & 1 & & D4 & $1 / 2$ & 2 & 3 & 1 & D9 & 2 & 2 & 3 & $1 / 3$ & 1 \\
\hline
\end{tabular}

\begin{tabular}{l|llllllll} 
C4 & D10 & D11 & D12 & D13 & D14 & D15 & D16 & D17 \\
\hline D10 & 1 & 3 & 2 & $1 / 2$ & 1 & $1 / 2$ & 4 & $1 / 2$ \\
D11 & $1 / 3$ & 1 & $1 / 2$ & $1 / 4$ & $1 / 3$ & $1 / 4$ & 2 & $1 / 4$ \\
D12 & $1 / 2$ & 2 & 1 & $1 / 3$ & $1 / 2$ & $1 / 3$ & 3 & $1 / 3$ \\
D13 & 2 & 4 & 3 & 1 & 2 & 1 & 5 & 1 \\
D14 & 1 & 3 & 2 & $1 / 2$ & 1 & $1 / 2$ & 4 & $1 / 2$ \\
D15 & 2 & 4 & 3 & 1 & 2 & 1 & 5 & 1 \\
D16 & $1 / 4$ & $1 / 2$ & $1 / 3$ & $1 / 5$ & $1 / 4$ & $1 / 5$ & 1 & $1 / 5$ \\
D17 & 2 & 4 & 3 & 1 & 2 & 1 & 5 & 1
\end{tabular}

\begin{tabular}{l|llll} 
C5 & D18 & D19 & D20 & D21 \\
\hline D18 & 1 & 2 & $1 / 3$ & $1 / 2$ \\
D19 & $1 / 2$ & 1 & $1 / 4$ & $1 / 3$ \\
D20 & 3 & 4 & 1 & 2 \\
D21 & 2 & 3 & $1 / 2$ & 1
\end{tabular}

\begin{tabular}{l|llll}
$\mathrm{C} 7$ & $\mathrm{D} 25$ & $\mathrm{D} 26$ & $\mathrm{D} 27$ & $\mathrm{D} 28$ \\
\hline $\mathrm{D} 25$ & 1 & 1 & $1 / 2$ & $1 / 3$ \\
$\mathrm{D} 26$ & 1 & 1 & $1 / 2$ & $1 / 3$ \\
$\mathrm{D} 27$ & 2 & 2 & 1 & $1 / 2$ \\
$\mathrm{D} 28$ & 3 & 3 & 2 & 1
\end{tabular}

\begin{tabular}{c|ccl} 
C8 & D29 & D30 & D31 \\
\hline D29 & 1 & 2 & 3 \\
D30 & $1 / 2$ & 1 & 2 \\
D31 & $1 / 3$ & $1 / 2$ & 1
\end{tabular}

\begin{tabular}{l|lll} 
C6 & D22 & D23 & D24 \\
\hline D22 & 1 & 2 & 1 \\
D23 & $1 / 2$ & 1 & $1 / 2$ \\
D24 & 1 & 2 & 1
\end{tabular}

\begin{tabular}{l|ll} 
C10 & D34 & D35 \\
\hline D34 & 1 & $1 / 2$ \\
D35 & 2 & 1
\end{tabular}

\begin{tabular}{l|ll} 
C12 & D38 & D39 \\
\hline D38 & 1 & $1 / 2$ \\
D39 & 2 & 1
\end{tabular}

\begin{tabular}{c|ccl} 
C13 & D40 & D41 & D42 \\
\hline D40 & 1 & 2 & 2 \\
D41 & $1 / 2$ & 1 & 1 \\
D42 & $1 / 2$ & 1 & 1
\end{tabular}

\begin{tabular}{l|ll} 
C9 & D32 & D33 \\
\hline D32 & 1 & 2 \\
D33 & $1 / 2$ & 1
\end{tabular}

\begin{tabular}{l|ll} 
C11 & D36 & D37 \\
\hline D36 & 1 & $1 / 2$ \\
D37 & 2 & 1
\end{tabular}

\begin{tabular}{l|rrrrr}
$\mathrm{U}$ & $\mathrm{U} 1$ & $\mathrm{U} 2$ & $\mathrm{U} 3$ & $\mathrm{U} 4$ & $\mathrm{U} 5$ \\
\hline $\mathrm{U} 1$ & 1.00000 & 2.00000 & 0.50000 & 0.33333 & 0.50000 \\
$\mathrm{U} 2$ & 0.50000 & 1.00000 & 0.33333 & 0.25000 & 0.33333 \\
$\mathrm{U} 3$ & 2.00000 & 3.00000 & 1.00000 & 0.50000 & 1.00000 \\
$\mathrm{U} 4$ & 3.00000 & 4.00000 & 2.00000 & 1.00000 & 2.00000 \\
$\mathrm{U} 5$ & 2.00000 & 3.00000 & 1.00000 & 0.50000 & 1.00000
\end{tabular}

Figure 1. All judgment matrix on every layer

\subsection{Weight Calculation}

The eigenvectors of normalization of judgment matrix from its eigenvalue of maximum is the weight which is this hierarchy factors relative to the level of the relative importance of one factor.

First, calculate all the elements in each row of the product of the NTH root in $\mathrm{n}$ order P judgment matrix, then get the vector $\mathrm{V}$. 


$$
V_{i}=\sqrt[n]{\prod_{j=1}^{n} a_{i j}}(n=1,2,3 \cdots n)
$$

Second, calculate relative eigenvector $\mathrm{W}$ according to $\mathrm{V}$.

$$
W_{\bar{i}}=\frac{V_{\bar{i}}}{\sum_{j=1}^{n} V_{j}}(n=1,2,3-\cdot n)
$$

Third, calculate the eigenvalue $\lambda$ of maximum of judgment matrix P.

$$
\lambda_{\text {.x }}=\frac{1}{n} \sum_{i=1}^{n} \frac{P W_{i}}{W_{i}}(n=1,2,3--n)
$$

$\lambda$ is used for consistency check of judgment matrix. Figuring out CI and CR can determine rationality of judgment matrix.

\subsection{Consistency Test of Judgment Matrix}

Because the judgment matrix is calculated by the people with subjectivity, judgment matrix which has been established actually is not completely consistent with the reference of consistency test to evaluate the reliability of the judgment matrix. From above results, CI of all the second order judgment matrix equal 0 , CI from all more than the second order of judgment matrix are less than 0.1. So judgment matrix passes the consistency test, the result is credible.

\section{Conclusion}

Researcher calculated weight of index and made them rounded. Then total steel industry credit rating index system was finished. Because City Commercial Banks mainly face the local enterprises, they need to summarize features from local enterprises. If a City Commercial Bank wants to apply this index system to practice, it needs to consider other factors and makes a change according to its clients. Some weights are very low, if they are not practical enough, user should delete them according to the need. Therefore, by investigating the bank as an example, some indexes was

\begin{tabular}{|c|c|c|c|c|}
\hline target layer & criterion layer & index layer & weight & $\begin{array}{l}\text { Final } \\
\text { score }\end{array}$ \\
\hline \multirow{5}{*}{$\begin{array}{l}\text { Market } \\
\text { Evaluation } \\
\text { U1 }\end{array}$} & \multirow{4}{*}{$\begin{array}{l}\text { Industry Status } \\
\mathrm{C} 1\end{array}$} & Supply and Demand D1 & 0.49 & 3 \\
\hline & & Supplier for Ability D2 & 0.16 & 2 \\
\hline & & Cycle D3 & 0.1 & 0 \\
\hline & & Policy Support D4 & 0.28 & 1 \\
\hline & \multicolumn{2}{|c|}{ Market Competition Condition C2 } & 6 & 6 \\
\hline \multirow{12}{*}{$\begin{array}{l}\text { Enterprise } \\
\text { Basic } \\
\text { Quality U2 }\end{array}$} & \multirow{5}{*}{$\begin{array}{l}\text { Leader's } \\
\text { Qualities C3 }\end{array}$} & Business Performance D5 & 0.12 & 0 \\
\hline & & Decision-making Ability D6 & 0.12 & 0 \\
\hline & & Experience D7 & 0.07 & 0 \\
\hline & & Personal Qualities D8 & 0.77 & 4 \\
\hline & & Credit Record D9 & 0.21 & 2 \\
\hline & \multirow{7}{*}{$\begin{array}{l}\text { Enterprise } \\
\text { Management } \\
\text { level C4 }\end{array}$} & Total Assets D10 & 0.13 & 0 \\
\hline & & Organizational System D11 & 0.05 & 0 \\
\hline & & Business Model D12 & 0.07 & 0 \\
\hline & & Marketing Ability D13 & 0.21 & 0 \\
\hline & & Previous Sales D14 & 0.07 & 0 \\
\hline & & Sales Revenue D15 & 0.21 & 1 \\
\hline & & $\begin{array}{l}\text { Company Worker Quality } \\
\text { D16 }\end{array}$ & 0.03 & 0 \\
\hline
\end{tabular}
adjusted, the results are shown in the following as Table 1.

Table 1. All indexes, their weights and scores are in three layers 


\begin{tabular}{|c|c|c|c|c|}
\hline & & \multirow[b]{2}{*}{$\begin{array}{l}\text { Financial Management Level } \\
\text { D17 }\end{array}$} & \multirow[b]{2}{*}{0.21} & \multirow[b]{2}{*}{1} \\
\hline & & & & \\
\hline \multirow{16}{*}{$\begin{array}{l}\text { Financial } \\
\text { Evaluation } \\
\text { U3 }\end{array}$} & \multirow{4}{*}{$\begin{array}{l}\text { Operating } \\
\text { Capacity C5 }\end{array}$} & Total Asset Turnover D18 & 0.16 & 0.6 \\
\hline & & Current Assets Turnover D19 & 0.09 & 0.4 \\
\hline & & Inventory Turnover D20 & 0.46 & 2 \\
\hline & & $\begin{array}{l}\text { Accounts } \\
\text { Turnover D21 }\end{array}$ & 0.27 & 1 \\
\hline & \multirow[t]{3}{*}{ Profitability C6 } & Return on Equity D22 & 0.4 & 0.8 \\
\hline & & Return on Total Assets D23 & 0.2 & 0.3 \\
\hline & & Return on Sales D24 & 0.4 & 0.9 \\
\hline & \multirow[t]{4}{*}{ Solvency C7 } & Asset-liability Ratio D25 & 0.14 & 1 \\
\hline & & Current Ratio D26 & 0.14 & 1 \\
\hline & & Quick Ratio D27 & 0.26 & 2 \\
\hline & & $\begin{array}{l}\text { Cash to Current Liability } \\
\text { Ratio D28 }\end{array}$ & 0.45 & 3 \\
\hline & \multirow[t]{3}{*}{$\begin{array}{l}\text { Growth Ability } \\
\text { C8 }\end{array}$} & $\begin{array}{l}\text { Sales Revenue Growth Rate } \\
\text { D29 }\end{array}$ & 0.53 & 1 \\
\hline & & Profit Growth D30 & 0.27 & 0.7 \\
\hline & & $\begin{array}{l}\text { Total Assets Growth Rate } \\
\text { D31 }\end{array}$ & 0.16 & 0.3 \\
\hline & \multirow[t]{2}{*}{$\begin{array}{l}\text { Ability to } \\
\text { Obtain Cash C9 }\end{array}$} & $\begin{array}{l}\text { Cash Recovery for Assets } \\
\text { D32 }\end{array}$ & 0.66 & 5 \\
\hline & & The Sale Cash Ratio D33 & 0.33 & 2 \\
\hline \multirow{7}{*}{$\begin{array}{l}\text { Enterprise } \\
\text { Supply } \\
\text { Chain Level } \\
\text { U4 }\end{array}$} & \multirow{3}{*}{$\begin{array}{l}\text { Cooperate with } \\
\text { Supplier C10 }\end{array}$} & Raw Material Supply Scale & 0.33 & 2 \\
\hline & & D34 & & \\
\hline & & $\begin{array}{l}\text { The changes in risk and } \\
\text { countermeasure D35 }\end{array}$ & 0.66 & 4 \\
\hline & \multirow{2}{*}{$\begin{array}{l}\text { Work with } \\
\text { Vendors C11 }\end{array}$} & Sellers Share Sales D36 & 0.33 & 7 \\
\hline & & $\begin{array}{l}\text { The Changes in Risk and } \\
\text { Countermeasure D37 }\end{array}$ & 0.66 & 13 \\
\hline & \multirow{2}{*}{$\begin{array}{l}\text { Cooperate with } \\
\text { Customer } \\
\text { Degree of } \mathrm{C} 12\end{array}$} & Customer Satisfaction D38 & 0.33 & 3 \\
\hline & & $\begin{array}{l}\text { The Customer's Recognition } \\
\text { of the Brand D39 }\end{array}$ & 0.66 & 8 \\
\hline \multirow{4}{*}{$\begin{array}{l}\text { The } \\
\text { Performance } \\
\text { Status U5 }\end{array}$} & \multirow{3}{*}{$\begin{array}{l}\text { Credit Status in } \\
\text { Bank } \mathrm{C} 13\end{array}$} & Deposit and Settlement D40 & 0.5 & 3 \\
\hline & & Loan Repayment D41 & 0.25 & 2 \\
\hline & & Mortgage Guarantee D42 & 0.25 & 2 \\
\hline & \multicolumn{2}{|c|}{ Commercial Credit Conditions C14 } & 15 & 15 \\
\hline
\end{tabular}

\section{Some Problems in Application}

Credit rating system can be divided objectively certain types of enterprise into some grades, but it does not work in some special conditions. In general, every credit rating system needs to add an instruction of special condition. For example, most Banks refuse enterprises which exist less than a year to get credit rating grades, because bank can be aware of the situation of enterprise exactly by credit rating system. The contents of different banks are very different. In reality, bank uses credit rating systems and instructions of special condition together to distinguish enterprises credit rating grade.

\section{References}

Mao, L. M. (2014). Small Medium Enterprise Credit Rating Index System and Model Research. Tongling College Journal, (1), 46-49.

Qiao, W. (2011). The Construction of Small Medium Enterprise Credit Rating Index System and Model. Journal of Kaifeng University, (4), 89-93.

Qiu, J., \& Chen, J. S. (2014). Some Countermeasures for Constructing the Index System of Small Medium Enterprise Credit Rating Analysis. Commercial Economy, (8), 95-96.

Zuo, R., \& Liu, Z. (2015). Based on the AHP Method to Build Small Medium Enterprise Credit Rating Index System. Communication of Finance and Accounting, (11), 80-83. 